\title{
SATELLITE BASED LIVE AND INTERACTIVE DISTANCE LEARNING PROGRAM IN THE FIELD OF GEOINFORMATICS - A PERSPECTIVE OF INDIAN INSTITUTE OF REMOTE SENSING, INDIA
}

\author{
P.L.N. Raju ${ }^{\text {a }} *$, P. K. Gupta ${ }^{\text {b }}$ P.S. Roy ${ }^{\mathrm{c}}$ \\ ${ }^{a}$ IIRS, Head, Geoinformatics Division, 4 Kalidas Road, Dehradun - 248001, India - raju@iirs.gov.in \\ b IIRS, Scientist “SC”, Geoinformatics Division, 4 Kalidas Road, Dehradun - 248001, India - prasun@iirs.gov.in \\ ${ }^{\mathrm{c}}$ IIRS, Director, 4 Kalidas Road, Dehradun - 248001, India - director@iirs.gov.in
}

Commission VI, WG VI/4

KEY WORDS: Distance Learning Program, Satellite based live programs, EDUSAT, Outreach for Universities, Geoinformatics

\begin{abstract}
:
Geoinformatics is a highly specialized discipline that deals with Remote Sensing, Geographical Information System (GIS), Global Positioning System (GPS) and field surveys for assessing, quantification, development and management of resources, planning and infrastructure development, utility services etc. Indian Institute of Remote Sensing (IIRS), a premier institute and one of its kinds has played a key role for capacity Building in this specialized area since its inception in 1966. Realizing the large demand, IIRS has started outreach program in basics of Remote Sensing, GIS and GPS for universities and institutions.
\end{abstract}

EDUSAT (Educational Satellite) is the communication satellite built and launched by ISRO in 2004 exclusively for serving the educational sector to meet the demand for an interactive satellite based distance education system for the country. IIRS has used EDUSAT (shifted to INSAT 4 CR recently due to termination of services from EDUSAT) for its distance learning program to impart basic training in Remote Sensing, GIS and GPS, catering to the universities spread across India. The EDUSAT based training is following similar to e-learning method but has advantage of live interaction sessions between teacher and the students when the lecture is delivered using EDUSAT satellite communication. Because of its good quality reception the interactions are not constrained due to bandwidth problems of Internet. National Natural Resource Management System, Department of Space, Government of India, under Standing Committee in Training and Technology funded this unique program to conduct the basic training in Geoinformatics.

IIRS conducts 6 weeks basic training course on "Remote Sensing, GIS and GPS" regularly since the year 2007. The course duration is spread over the period of 3 months beginning with the start of the academic year (1st semester) i.e., July to December every year, for university students. IIRS has utilized EDUSAT satellite for conducting 4 six weeks training course during 2007 till 2009 and INSAT 4CR for conducting the next 2 programs. Till March 2011, fifty four universities with the participation of over 4000 students have benefited from the program (Table 7 and Figure 8). IIRS also organized workshops on "EDUSAT based distance learning: experiences \& future learning" in 2007, 09 and 2011. Feedbacks have been taken to address the issues on course structure, duration etc. and plan for improvement in future programs and wider participation. Majority of the participants expressed satisfaction and provided positive feedback and willing to participate in the future programs.

\section{INTRODUCTION}

\subsection{Background}

Distance education (DE), or distance learning, is a field of education that focuses on the technology and instructional systems design that are effectively incorporated in delivering education to students who are not physically "on site" to receive their education. Instead, teachers and students may communicate asynchronously (at times of their own choosing) by exchanging printed or electronic media, or through technology that allows them to communicate in real time (synchronously). DE courses that require a physical on-site presence for any reason including the taking of examinations is considered to be a hybrid or blended course or program. Modern DE has been around at least since Isaac Pitman taught shorthand in Great Britain via correspondence in the 1840s (Moore et.al. 2005), since "the development of the postal service in the 19th century. Commercial correspondence colleges provided DE to students across the country." Computers and the Internet have only made distance learning easier, just as it has for many other day-to-day tasks (Phipps R. and Merisotis, J., 1999).

Indira Gandhi Open University National Open University (IGNOU) established in 1985 and is considered to be the largest in terms of intake i.e. 3.0 million students (http://www.ignou.ac.in, 2011) as shown in table 1. One of the oldest DE universities is the University of South Africa, which has been offering correspondence Education courses since 1946 (established in 1873) with intake of students i.e. 13,800 (Jung I, 2005). The largest DE university in the United Kingdom is the Open University founded 1969 with student intake i.e. 1.6 Million. In Germany the Fern Universität in Hagen was founded 1974. There are now many similar institutions around the world, offer DE with the name Open University (in English or

\footnotetext{
* Corresponding Author.
} 
in the local language). There are many private and public, nonprofit and for-profit institutions offering courses and degree programs through DE (Wikipedia contributors, Distance Education, 2010).

\begin{tabular}{|l|c|c|}
\hline Institution & $\begin{array}{c}\text { Year of } \\
\text { Establishment }\end{array}$ & $\begin{array}{c}\text { Number of DE } \\
\text { Students }\end{array}$ \\
\hline IGNOU (India) & 1985 & $3,000,000$ \\
\hline $\begin{array}{l}\text { Open University } \\
\text { (UK) }\end{array}$ & 1969 & $1,600,000$ \\
\hline $\begin{array}{l}\text { University of South } \\
\text { Africa, (South } \\
\text { Africa) }\end{array}$ & 1873 & $\begin{array}{c}13,800 \text { (UNISA, } \\
2011)\end{array}$ \\
\hline
\end{tabular}

Table 1. Profile of "Mega Universities" offering Distance Education. Adapted from (Jung, 2005) \& updated June 2011

\subsection{Other Distance Learning in India and Worldwide (Gupta et al, 2011)}

Various studies have been done on the availability of distance learning courses in India (Patel D, 2006) and worldwide (Jung, 2005). The courses are either available through public domain networks such as the Internet or private networks such as satellite or wired/wireless local networks. E-learning and Information Communication Technology (ICT) have proved to be a boon for participants of DE. The UN specialised agency for telecommunications ITU states that as of 2009 , the estimated number of Internet users per 100 inhabitants in India is a meagre 5.12, as compared to 39.22, 29.00 and 28.90 of Brazil, Russia and China, respectively (ITU, 2011). This unavailability of high speed internet connections in parts of India has given a definite edge to satellite based educational networks which needs to be exploited. In India, IGNOU and state open universities are the two major bodies imparting $\mathrm{DE}$ at professional level. IGNOU offers a plethora of programs across its 21 schools (IGNOU, 2011). Although the scale at which the programs are conducted is large, standalone organisations can learn important lessons on conducting professional courses as outreach programs. In Indian context, Rajashekhar et al., (2010) points out that satellite communication technology are the "only solution" as the majority $(70 \%)$ of the Indian population lives in inaccessible rural areas along with various economic, cultural, demographical and topographical conditions. Enabling relevant users and institutions to take education to all parts of the country is also one of the goals of the Indian Space Research Organisation (ISRO) (Bhaskaranarayana et al., 2009).

\subsection{Distance Education in Geoinformatics}

Geoinformatics is highly specialized discipline that deals with Remote Sensing, Geographical Information System, Global Positioning System and field surveys for assessing, quantification, development and management of resources. Training in this specialized field is essential for its effective utilization. Few universities / Institutions in India started offering Distance Education in Geoinformatics at Masters / Diploma/Certificate course level. Table 2 provides details of courses offered in India.

\begin{tabular}{|l|c|c|}
\hline Course name & Duration & Institute /university \\
\hline $\begin{array}{l}\text { M.Sc. in } \\
\text { Geoinformatics }\end{array}$ & 2 Years & $\begin{array}{c}\text { Indian Institute of Ecology and } \\
\text { Environment }\end{array}$ \\
\hline
\end{tabular}

\begin{tabular}{|l|c|c|}
\hline $\begin{array}{l}\text { M.Sc. in } \\
\text { Geoinformatics }\end{array}$ & 2 Years & $\begin{array}{c}\text { Sikkim Manipal University } \\
\text { Directorate of Distance Education }\end{array}$ \\
\hline $\begin{array}{l}\text { M.Sc. in } \\
\text { Geoinformatics }\end{array}$ & 2 Years & $\begin{array}{c}\text { Annamalai University Directorate } \\
\text { of Distance Education }\end{array}$ \\
\hline $\begin{array}{l}\text { Postgraduate } \\
\text { Diploma in } \\
\text { Geoinformatics }\end{array}$ & 1 Year & Uttarakhand Open university \\
\hline $\begin{array}{l}\text { Certificate } \\
\text { course in } \\
\text { Geoinformatics }\end{array}$ & 6 Months & Uttarakhand Open university \\
\hline $\begin{array}{l}\text { M.Sc. in } \\
\text { Geoinformatics }\end{array}$ & 2 Years & UNIGIS India \\
\hline $\begin{array}{l}\text { Professional } \\
\text { Diploma in } \\
\text { Geoinformatics }\end{array}$ & 1 year & UNIGIS India \\
\hline $\begin{array}{l}\text { Remote } \\
\text { Sensing, GIS } \\
\text { and GPS }\end{array}$ & 3 Months & $\begin{array}{l}\text { Indian Institute of Remote Sensing } \\
\text { (Unique and satellite based) }\end{array}$ \\
\hline
\end{tabular}

Table 2. Distance Education Programs in India

Table 3 provides details of some GIS courses offered internationally.

\begin{tabular}{|l|c|c|}
\hline Course & Duration & University \\
\hline $\begin{array}{l}\text { Online Master of } \\
\text { Education in Earth } \\
\text { Sciences }\end{array}$ & $2+$ years & $\begin{array}{c}\text { Penn State University, } \\
\text { World Campus }\end{array}$ \\
\hline $\begin{array}{l}\text { Master of Geographic } \\
\text { Information Systems }\end{array}$ & $2+$ years & $\begin{array}{c}\text { Penn State University, } \\
\text { World Campus }\end{array}$ \\
\hline $\begin{array}{l}\text { Graduate Certificate in } \\
\text { Geospatial Intelligence }\end{array}$ & $2+$ years & $\begin{array}{l}\text { Penn State University, } \\
\text { World Campus }\end{array}$ \\
\hline $\begin{array}{l}\text { Post baccalaureate } \\
\text { Certificate in Geographic } \\
\text { Information Systems }\end{array}$ & $1+$ years & $\begin{array}{l}\text { Penn State University, } \\
\text { World Campus }\end{array}$ \\
\hline $\begin{array}{l}\text { Master of Science } \\
\text { (Geographic Information } \\
\text { Science and Systems }\end{array}$ & $2+$ years & $\begin{array}{c}\text { UNIGIS International } \\
\text { Association }\end{array}$ \\
\hline $\begin{array}{l}\text { Professional Diploma / } \\
\text { Certificate in GIS }\end{array}$ & $1+$ year & $\begin{array}{c}\text { UNIGIS International } \\
\text { Association }\end{array}$ \\
\hline $\begin{array}{l}\text { Various Certificate } \\
\text { courses }\end{array}$ & $6-9$ weeks & ITC, The Netherlands \\
\hline $\begin{array}{l}\text { Master's program in } \\
\text { Geographical } \\
\text { Information Systems } \\
\text { (GIS) }\end{array}$ & 2 years & $\begin{array}{c}\text { Lund University GIS } \\
\text { Centre, Sweden }\end{array}$ \\
\hline $\begin{array}{l}\text { Certificate/ Diploma / } \\
\text { Master's degree in GIS }\end{array}$ & $1 / 2 / 3$ years & $\begin{array}{c}\text { University of Leeds \& } \\
\text { Southampton, UK }\end{array}$ \\
\hline $\begin{array}{l}\text { GIS Certificate Program } \\
\text { Johns Hopkins } \\
\text { University }\end{array}$ \\
\hline $\begin{array}{l}\text { Online Undergraduate } \\
\text { GIS Certificate Course }\end{array}$ & 1 year & $\begin{array}{c}\text { University of West } \\
\text { Florida }\end{array}$ \\
\hline $\begin{array}{l}\text { Online Graduate GIS } \\
\text { Certificate Course }\end{array}$ & 1 year & $\begin{array}{c}\text { University of West } \\
\text { Florida }\end{array}$ \\
\hline
\end{tabular}

Table 3. Major Distance Education Programs at International Level

Majority of the distance learning programs on the basis on payment except few courses like IIRS Satellite based outreach program and Lund University M.Sc. program. Many Indian courses are quite cheaper compared to International programs and the quality also varies proportionately. 


\section{IIRS OUTREACH PROGRAM}

\subsection{IIRS DE Initiative}

IIRS, the first of its kind has played a key role in capacity Building of midterm career professionals from in-service institutions of India and many developing countries in its four decades of dedicated service (P.S. Roy,2000; B.L. Deekshatulu and P.S. Roy, 2000; P.L.N. Raju et. al., 2007; Dadhwal, V.K. and P.L.N. Raju, 2007; IIRS website, 2011).

The EDUSAT based basic training in Geoinformatics is distance education designed and developed as an exclusive program for universities spread across India. This section of the paper describes about EDUSAT satellite that was dedicated for distance education, uniqueness of capacity building program of Geoinformatics that was launched using EDUSAT, IIRS experiences in successful organization of six courses in Geoinformatics as part of its outreach program.

\subsection{Unique nature of satellite based distance learning}

Contact based training though advantageous and beneficial; it is not possible for many to attend due to time limitations, financial constraints and importantly day-to-day commitments at work place, as explained under Distance Learning benefits section. The type of distance education can be different depending on technology and tools used. The first among them is distance education (correspondence courses) supported with printed material but with or without study centers. In the present age "Internet based courses" are replacing the conventional correspondence courses. The advanced type of courses are "elearning" where the student can avail the content of the course through the internet, stream the lectures using the internet and have interaction with teachers on a specified date and time. They can be provided FAQs (Frequently Asked Questions) and quiz materials for easy learning. The students can appear at examinations on specified date and location. The EDUSAT based training is following similar like e-learning method but has advantage of live interaction sessions between teacher and the students when the lecture is delivered using EDUSAT satellite communication. It is advantageous because of its good quality reception and interactions are not constrained due to bandwidth problems of Internet.

EDUSAT satellite services are wide spread and gained momentum over the time. So far 45 broadcast and interactive networks have been established by Indian Space Research Organisation (ISRO), Department of Space (DOS), covering 20 states with having more than 30, 000 classrooms under EDUSAT network. (ISRO Press release, 2008 \& EDUSAT satellite, 2008). It is likely to expand over the time as more and more users are showing keen interest to utilize the services of EDUSAT.

Indian Institute of Technology. Mumbai is offering EDUSAT based online and offline courses in Engineering disciplines since January 2008 for a minimum of 30 institutions spread all over India. The disciplines offered under the Centre for Distance Engineering Education Program (CDEEP) are soil mechanics, instrumentation and process control, signals and systems, adoptive signal processing, object oriented systems, sheet metal engineering, computation fluid dynamics and HT, wavelets, IT project management, information systems, fiber optics communications, software engineering, solid state microwave devices. (CDEEP Distance Education, 2008). In addition, CDEEP offering many online and virtual courses in Engineering in different modes like free EDUSAT courses (http://www.cdeep.iitb.ac.in/Live_edu/index.html), live webcast courses (http://www.cdeep.iitb.ac.in/solo/), National Project for Technology Enhanced Learning (NPTEL) courses freely to enhance the quality of engineering education.

\subsection{EDUSAT Utilization at IIRS for the Training}

The use of Geomatics i.e. Remote Sensing, Geographic Information System (GIS), Global Positioning System (GPS) and associated geo-spatial technologies is increasing rapidly, thereby demand for more capacity building and institutionalization of the technology. IIRS is utilizing the EDUSAT facility for these purposes. Initially the program is offered to twelve universities who have shown keen interest to participate. National Natural Resource Management System, Department of Space, Government of India has funded this unique program to conduct the basic training in Geomatics to undergraduate / postgraduate level students of Indian universities.

Teaching studio is the prerequisite to broadcast live telecast EDUSAT based training. Accordingly IIRS has established its own Teaching end Studio and Up-linking facility in the campus under national beam coverage of EDUSAT and link with users. IIRS has given opportunity to all the universities with the following guidelines if they are willing to participate in the training program that was proposed using EDUSAT:

- University/Institute supports its own EDUSAT classroom facility for the planned training.

- University/Institute meets its own financial expenditure for the training at their place. IIRS will meet all its expenses at teaching end i.e. IIRS, Dehradun.

- Identified focal point at University to coordinate day to day activity requirements of the planned training program.

- University/Institute will be responsible for arranging the EDUSAT classroom for the scheduled training program, registering students for the training, attendance of students and taking care of all needs as and when required.

IIRS will be responsible to conduct the training with the support of scientific faculty from the teaching end studio established at IIRS. The proposed training will be conducted using $\mathrm{Ku}$ band, National Beam of EDUSAT under CEC-UGC (Consortium for Educational Communication - University Grants Commission) network. Feedback / end of the program workshop to be conducted at IIRS with the participation of University/Institute foal point/coordinators. IIRS will support the travel cost for a minimum of one person from each centre.

\subsection{Course Structure and Curriculum}

IIRS conducted basic training course on "Remote Sensing, Geographical Information System and Global Positioning System" spread over 3 months for university students. The course dealt the basics in detail supported with simple examples to generate more interest and encourage them to interact more. In addition IIRS has started one shorter course in "Advances course in Geoinformatics" since 2011. Outline of these courses 
and curriculum of the program as given in Table 4 and 5 respectively.

\begin{tabular}{|c|c|}
\hline Module Topic & Duration \\
\hline $\begin{array}{l}\text { Remote Sensing \& Digital Image } \\
\text { Processing (Module 1) } \\
\text { Principles, platforms \& sensors, thermal \& } \\
\text { MW Remote Sensing, spectral properties, } \\
\text { atmospheric interactions, satellite data } \\
\text { products, pre-processing, enhancement } \\
\text { techniques, geometric corrections, } \\
\text { supervised and unsupervised classification } \\
\text { algorithms }\end{array}$ & $\begin{array}{l}2 \text { Weeks } \\
\text { Total } 20 \text { hrs }(10 \\
\text { hrs lectures, } 5 \mathrm{hrs} \\
\text { interaction } \\
\text { /discussion, } 5 \\
\text { hrs } \\
\text { demonstration/ } \\
\text { hands on) }\end{array}$ \\
\hline $\begin{array}{l}\text { Global Positioning System (Module 2) } \\
\text { Overview of GPS, constellation and } \\
\text { functionality, navigation principles, code } \\
\text { and carrier measurements, GPS errors, } \\
\text { differential GPS, surveying methods, } \\
\text { applications and comparison of different } \\
\text { navigation systems }\end{array}$ & $\begin{array}{l}1 \text { Week } \\
\text { Total } 10 \text { hrs }(5 \\
\text { hrs lectures, } 2.5 \\
\text { hrs interaction } \\
\text { /discussion and } \\
2.5 \text { hrs } \\
\text { demonstration/ } \\
\text { hands on) } \\
\end{array}$ \\
\hline $\begin{array}{l}\text { Geographical Information System } \\
\text { (Module 3) } \\
\text { Overview of GIS, spatial data models (vector } \\
\text { \& raster), data formats and structures, non } \\
\text { spatial data models, inputting, editing and } \\
\text { creation of topology, H/W \& S/W for GIS, } \\
\text { coordinate systems, datum, projection, } \\
\text { spatial analysis, network analysis, digital } \\
\text { elevation models and applications, } \\
\text { cartography, visualisation, output generation } \\
\text { and web resources of GIS }\end{array}$ & $\begin{array}{l}2 \text { Weeks } \\
\text { Total } 20 \text { hrs }(10 \\
\text { hrs lectures, } 5 \mathrm{hrs} \\
\text { interaction } \\
\text { /discussion, } 5 \\
\text { hrs } \\
\text { demonstration } \\
\text { /hands on) }\end{array}$ \\
\hline $\begin{array}{l}\text { Applications and advances in RS, GIS and } \\
\text { GPS - (Module 4) } \\
\text { Operational RS applications in India, crop } \\
\text { area, type and yield forecasting, forest } \\
\text { inventory, ecosystem and biodiversity } \\
\text { characterisation, geology, geomorphology } \\
\text { and hydrogeology and engineering geology, } \\
\text { water resource assessment, watershed } \\
\text { development, irrigation water management, } \\
\text { flood and drought monitoring, oceanography } \\
\text { and coastal zone management, high } \\
\text { resolution satellite data and urban } \\
\text { applications. }\end{array}$ & $\begin{array}{l}1 \text { Week } \\
\text { Total } 16 \text { hrs (12 } \\
\text { hrs lectures, 4hrs } \\
\text { interaction } \\
\text { /discussion, ) }\end{array}$ \\
\hline
\end{tabular}

\section{Table 4. Course Curriculum of IIRS EDUSAT Program}

More emphasis is given to open source tools usage and practical hands in the seventh course conducted during August November 2011 and made it possible with linking OSGEOIndia initiatives.

\begin{tabular}{|l|l|}
\hline \multicolumn{1}{|c|}{ Module Topic } & \multicolumn{1}{c|}{ Duration } \\
\hline Advances in Geoinformatics & 4 weeks \\
Indian Space Program- Present \& Future, & Total 18hrs (12 hrs \\
Earth Observation \& Geoinformatics & lectures, 6hrs \\
Technological Trends, Spatial Databases, & interaction \\
Geo Data Modelling, Programming \& GIS & /demonstration) \\
Customization, Web GIS, Mobile & \\
Mapping, 3D GIS \& Visualisation, Tele & \\
Matics \& Transportation Systems. Spatial & \\
Decision Support System, Open Source & \\
GIS(OSGEO Live Demonstration) & \\
\hline
\end{tabular}

Table 5. Course Curriculum of "Advances in Geoinformatics"

\subsection{Approach of IIRS Outreach Program}

The training program lectures / practical / software demonstrations are live telecasted from IIRS teaching studio for one and half hour to two hour session on a specified time and date as per the announcement in advance to all the participating institutions. Daily programs are flashed in bulletin boards on daily basis at IIRS website. Presentation material and reading material are made available to all registered participants through ftp before commencement of live program.

Presentations are specially prepared on standard template with minimum font size of 24 for clarity and better viewing for the initial programs. Majority of the programs (i.e. 90\%) were conducted live. Special care was given with sufficient time for interactive sessions, like 15 minutes interactive time was allotted for 45- minute lecture. All participating universities using Microsoft NetMeeting interactive chatting program normally post questions. Teaching faculty through the video and audio channels answers all the questions interactively.

The programs are streamed using 384 KBPS for transmission of video with public domain audio and video streaming program (i.e. VLC). It is converted from VGA mode to PAL format and up linked to EDUSAT satellite in $\mathrm{Ku}$ band. It is down linked back under national beam so that all users equipped with EDUSAT SITs (Satellite Interactive Terminals) / ROTs (Receive Only Terminals). Registered participants from universities received these live lectures / demonstrations and interacted in the question / answer sessions.

There are many others who are having EDUSAT terminals as part of other networks under national beam, such as IGNOU (Indira Gandhi Open University), CIET-NCERT (Central Institute of Educational Technology - National Council for Educational Research and Training), AICTE (All India Council for Technical Education) can also receive our program but without interaction. Due to poor quality of transmission IIRS has shifted from VLC based streaming to L earning Management System (LMS) based streaming by using Train-net S/W as it facilitates high quality output.

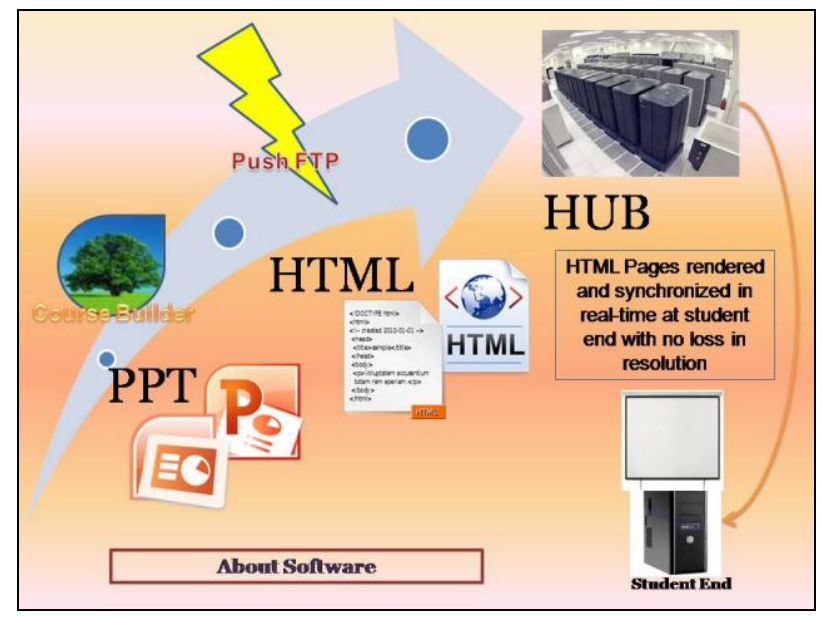

Figure 6. Schematic of LMS based High Quality Streaming using "TrainNet" 


\subsection{LMS based Online High Quality Streaming}

The "TrainNet" based LMS allows efficient bandwidth allocation to voice, video, data, reverse audio and reverse video. This allows real time audio-video interaction between the teaching end and student end. This software has many modules namely Course Builder, Push FTP, Teaching end and recorder personal computer (PC) modules. The course builder module converts the Microsoft Power Point Presentation into web based HTML format. Push FTP allows this HTML file and other materials to be transported over to multiple student ends in real time. Teaching PC has many capabilities such as chat, email, highlighter, video calling and slide navigation as shown in figure 6 . Recorder PC allows the student ends to view and record the sessions.

\subsection{Throughput of IIRS Outreach Program}

IIRS has utilized EDUSAT satellite for conducting 4 such training programs during 2007 till 2009 and INSAT 4CR for conducting the next 2 programs. Till March 2011, fifty four universities with the participation of over 4000 students have benefited from the program. IIRS organized workshops on "EDUSAT based distance learning: experiences \& future learning" in 2007, 09 and 2011, after the completion of the courses with an objective to review experiences of the course, address the issues on course structure, duration etc. and plan for future programs with wider participation. Majority of the participants expressed satisfaction and provided positive feedback and willing to participate in the future programs. Accordingly the seventh training program is planned to be conducted during August - November, 2011 with participation of 55 universities and more than 1000 students. Examinations will be conducted, evaluated and award of certificates to the successful candidates under IIRS outreach. Table 7 and Figure 8 shows distribution of universities participated in the training programs.

\section{CONCLUSION}

The present bottle necks in the distance/e-learning are mainly due to access to internet, broadband internet bandwidth and content development. However these issues are very well addressed with the dedicated EDUSAT satellite (replaced with INSAT 4CR) made available for satellite based live and interactive programs at country level meeting the demands of school to master /professional level higher education needs.

The response to IIRS outreach program is overwhelming and the demand is increasing over the years.

Satellite based distance education / training is very good alternative meeting the requirements users. This facility is limited to institutions /university/ Departments as it costs very high (US\$ 8000) for initial establishment, though the maintenance costs are not much.

Individuals may prefer internet as a medium for distance /elearning as it has more flexibility and longer time to learn.

The major limitation of distance classes' e-learning are:

- Real hands on with ground truth and field equipments

- Hands on experience of software tools

- Interaction and group discussions
Developments are already on for virtual learning in simulated environment, easy learning tutorials, discussion boards are also to some extent help in enhancing the learning.

The distance / e-learning programs are well structured and professionally managed at some of the well established institutions but the majority of them, particularly the Indian institutions / universities are primitive in richness of content, interactive facility, delivery system and access through internet.

\section{FUTURE PLANS}

More emphasis needs to be given on practical hands on and usage of Geoinformatics software tools. All have appreciated the use of free and open source tools (ILWIS for DIP and QGIS for GIS) during demonstrations.

The inclusion of LMS based learning will bring in improved interactivity, and hence attract more user base. Mostly positive feedback was received from participants and coordinators. Some issues highlighted by coordinators such as compensation was looked into at the end of the 5th course. An attempt to address participant apprehensions on more interactivity and advanced content was undertaken in the 6th course which was conducted on "Advances of Geoinformatics" using the new LMS “TrainNet".

In the future IIRS plans to address issues such as fixed timings and availability of content - by taking the content online (internet) using an open source Learning Management System (Moodle). By adding animations and graphical content - IIRS plans to grasp viewer attention for longer periods of time such that penetration of this technology is maximum among the masses. This will help India meet the major upcoming requirement of trained professionals in the field of Geoinformatics.

In the present status of e-learning delivery is based on single server access model. Increased number of users limits accessibility and takes considerable time; thereby the user loses the interest in e-learning based courses. To achieve seamlessly transfer of knowledge to students, advanced technologies like Content Delivery Networks (CDN) have to be employed. Service of a CDN can be used to boost our video web-portal and transparently distribute content for the purposes of improving performance and scalability. This will enable us to reach out to the masses, even those who do not have a broadband line to their universities or homes to view our videos uninterruptedly. Those having broadband connections will be able to view the videos without any framing or pixilation.

This will grab viewer attention, improve concentration and hence encourage participation enhanced content using animations and graphics need to be prepared. This enhanced content needs to be deployed using a Learning Management System (e.g., Moodle, an Open Source LMS) and then delivered through a $\mathrm{CDN}$ service provider.

\section{REFERENCES}

Bhaskaranarayana, A., Varadarajan, C. and Hegde, V.S., 2009, Space-based societal applications-Relevance in developing countries. Acta Astronautica, 65, pp. 1479 - 1486. 
B.L. Deekshatulu and P.S. Roy, 2000. Human Resources Development in Space Technology Applications. Space Forum Vol. 5, pp 239-257.

Gupta P.K., Raju PLN, Roy PS. 2011. User Response Analysis of IIRS Geomatics EDUSat Distance Learning Program and Future Challenges. Proceedings of ISPRS WG VI/4 International Workshop on "Multinational Geomatics Capacity Building - Achievements and Challenges", IIRS, April 7-8, 2011.

IGNOU, 2011. Data from IGNOU Website Accessed on June 18 , 2011

http://www.ignou.ac.in/ignou/aboutignou/profile/milestone >

ITU, 2011. WTI Information Technology Public Report Year 2009. http://www.itu.int/ITU-D/ICTEYE/Reports.aspx (accessed on March 26, 2011)

Jung I., 2005. Quality Assurance Survey of Mega Universities. In C. McIntosh (Ed.), Perspectives in Distance Education Lifelong Learning and Distance Higher Education. Canada: Commonwealth of Learning, pp. 79-95.

Moore, Michael G., Greg Kearsley, 2005. Distance Education: A Systems View, Second, Belmont, CA: Wadsworth. ISBN 0534-50688-7.

Open University, 2011. Data from Open University UK Website Accessed on June 18, 2011 < http://www8.open.ac.uk/about/main/the-ou-explained/facts-andfigures >

Patel, D., 2006, E-learning and its Impact on LIS profession. Conference on ICT for Facilitating Digital Learning Environments. Bangalore, paper $-\mathrm{X}$.

Phipps, Ronald; Merisotis, Jamie., 1999. What's the difference? A review of contemporary research on the effectiveness of distance learning in higher education. Institution for Higher Education Policy, WashingtonDC, http://www.eric.ed.gov/ERICDocs/data/ericdocssql/content_stor age_01/0000019b/80/17/87/09.pdf (accessed 22 Mar. 2008).

P.L.N. Raju, V.K. Dadhwal and C. Jeganathan, 2007, "GIS Education and Training at Indian Institute of Remote Sensing", GIS Development Asia Pacific, Mach 2007, Vol 11, Issue 3.

P.S. Roy, 2000. Indian Institute of Remote Sensing - Training, Education and Research Activities. Asian Journal of Geoinformatics Vol. 1 No. 1, pp 63-68.

Rajashekhar S.L., Ayyangar G.V. and Sharma R, 2010, Satellite-based Distance Education in Digital Paradigm: ISRO perspective. 6th International Conference on Digital Content Multimedia Technology and its Applications (IDC) IEEE, pp. 366-371.

V.K. Dadhwal and P.L.N. Raju, 2007. Four decades of capacity building in applications of space-based earth observation and Geoinformatics at Indian Institute of Remote Sensing, Proceedings of 58th International Astronautical Congress, organised at NRSA, Hyderabad during Sept. 24-28, 2007. IAC07-E1.I.08.

Wikipedia contributors, 2008. Distance education, Wikipedia, The

Free

Encyclopaedia.
http://en.wikipedia.org/w/index.php?title=Distance_education\& oldid-197963792 (accessed 22 Mar 2008).

\section{Internet References for List of Courses}

http://www.ecology.edu/iiee/geo-informatics.htm ttp://www.indiastudycenter.com/univ/states/sikkim/sikkimmanipal-university-of-health-medical-technological-sciencesdistance-education/courses/post-graduate-courses/mscgeoinformatics.asp http://www.indiastudycenter.com/Other/Syllabus/TN/Annamala i-University/Post-Graduate/MSc-Geo-Informatics/default.asp http://uou.ac.in/programme/cgis11 http://uou.ac.in/programme/pgdgis11

http://www.india.unigis.net http://www.iirs.gov.in

http://www.worldcampus.psu.edu http://www.unigis.net/study-with-UNIGIS/qualification http://www.itc.nl/CourseFinder http://luma.gis.lu.se/ http://www.geog.leeds.ac.uk/odl/structure.htm http://advanced.jhu.edu/academic/environmental/gis/index.html http://uwf.edu/gis/gisonline/ol_courses 
International Archives of the Photogrammetry, Remote Sensing and Spatial Information Sciences, Volume XXXVIII-6/W27, 2011 ISPRS Taipei 2011 Workshop, 4-6 October 2011, Taipei, Taiwan

\begin{tabular}{|c|c|c|c|c|c|c|c|}
\hline & I Course & II Course & III Course & IV Course & V Course & VI Course & Total \\
\hline Course Duration & $\begin{array}{c}\text { 29Jan07- } \\
\text { 9Apr07 }\end{array}$ & $\begin{array}{c}\text { 19Sep07- } \\
\text { 03Dec07 }\end{array}$ & $\begin{array}{c}\text { 25Aug08- } \\
\text { 20Nov08 }\end{array}$ & $\begin{array}{c}\text { 12Aug09- } \\
\text { 30Oct09 }\end{array}$ & $\begin{array}{c}4 \text { Oct10- } \\
\text { 9Dec10 }\end{array}$ & $\begin{array}{c}\text { 14Feb11- } \\
\text { 9Mar11 }\end{array}$ & 26 \\
\hline $\begin{array}{c}\text { Total Univ.'s } \\
\text { Participated }\end{array}$ & 12 & 22 & 40 & 48 & 10 & 54 \\
\hline $\begin{array}{c}\text { Total No. of } \\
\text { Participants }\end{array}$ & 349 & 931 & 915 & 931 & 982 & 179 & 4287 \\
\hline
\end{tabular}

Table 7. EDUSAT Course Participation Summary

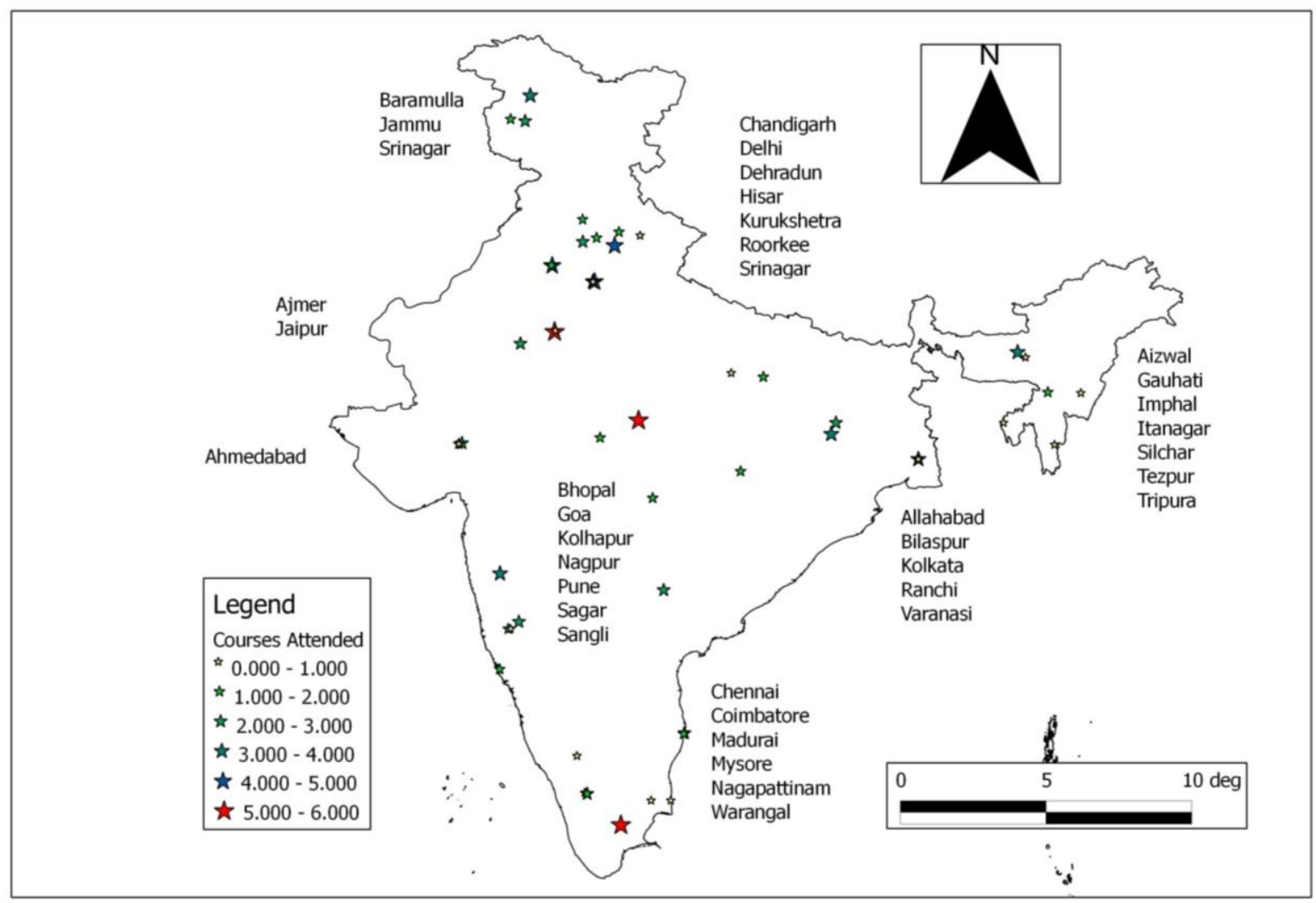

Figure 8. Distribution of Universities across India 